\title{
極超音速飛行体周りに形成される非平衡衝撃波層からの 輻射熱伝達に関する実験及び解析*1 \\ Radiative Heat Transfer from a Nonequilibrium Shock Layer \\ Generated around a Hypersonic Flight Model
}

\author{
小紫 公 也*2 笠 原 次 郎*3 \\ Kimiya KomURASAKI, Jiro KaSAHARA, \\ 矢野修二郎*3・藤 原 俊 隆*2 \\ Shujiro Yano and Toshi FuJiWara
}

Key Words: Shock Waves, Hypersonic Flow, Radiation, Heat Transfer, Ballistic Range

\begin{abstract}
Radiative heat transfer from the strong shock layer generated around a hypersonic flight model is experimentally investigated by using a ballistic range (two-stage light-gas gun). A plastic projectile of $1.2 \mathrm{~cm}$ diameter is accelerated in this facility up to $5.3 \mathrm{~km} / \mathrm{s}(M=15)$, and the radiation spectra and global power emission from the projectile are measured. As a result, radiation spectra from some carbon-containing molecules such as $\mathrm{CN}$ and $\mathrm{CO}$, were observed along with the air spectra, and the radiative heat transfer rate was estimated. Since the projectile launched in a ballistic range is two orders of magnitude smaller than the actual space vehicles, the model-dimension effect on shock layer structure is examined by analytical and numerical considerations, and a scaling law has been developed. Radiative heat transfer rate around a projectile was calculated, and the validity of conventional numerical model is discussed by comparing the computed result with the measured one.
\end{abstract}

記 号

$A ：$ 輻射を伴う電子励起準位間遷移速度

$D:$ 解離エネルギー, $\mathrm{J}$

$K:$ 電子の衝突による電子励起準位間遷移速度

$k_{t}, k_{\mathrm{r}}:$ 反応速度係数

$L:$ 衝撃波層の厚み, $\mathrm{m}$

$M:$ マッ八数

*1 平成 5 年 11 月 12 日原稿受理

*2 名古屋大学工学部機械・航空宇宙工学科

*3 名古屋大学大学院工学研究科

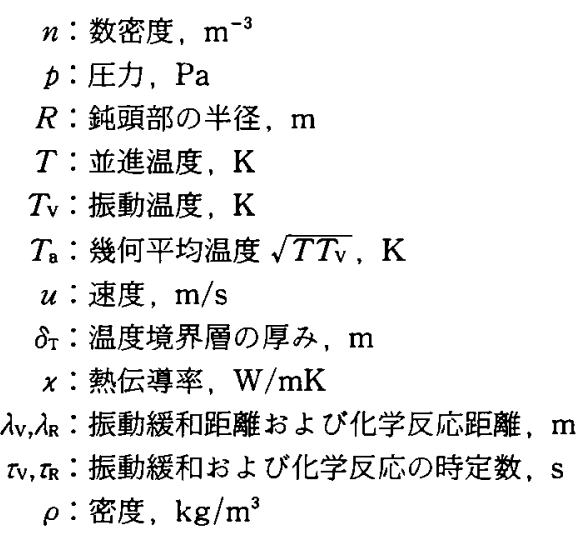

1.はじめに

近年スペースプレーンやAOTV (Aero-assisted Orbital Transfer Vehicle) などの極超音速飛行船の研 究が盛んに行なわれているが、これらが地球の大気圈 を飛行する際には大きな空力加熱が生じ，機体への熱 伝達量は数 $100 \mathrm{~kW} / \mathrm{m}^{2}$ 程度にもなるといわれてい る.そこで機体の熱防御は重要な課題となっており. 設計をする際には正確な熱伝達率の見積が必要とな る1,2) しかし，熱伝達機構のなかでも輻射を介した 熱伝達は，対流によるものよりも不確定な因子が多 く，まだ定量的な評価が難しい

この輻射熱伝達を研究するためには，極超音速かつ 高エンタルピーな空気の流れを実験室で作り出す必要 があり，非常に大掛かりな設備を必要とする。そのた めこれまでは主として大型コンピュータを用いた数值 解析によって輻射熱伝達量の見積が試みられてき 


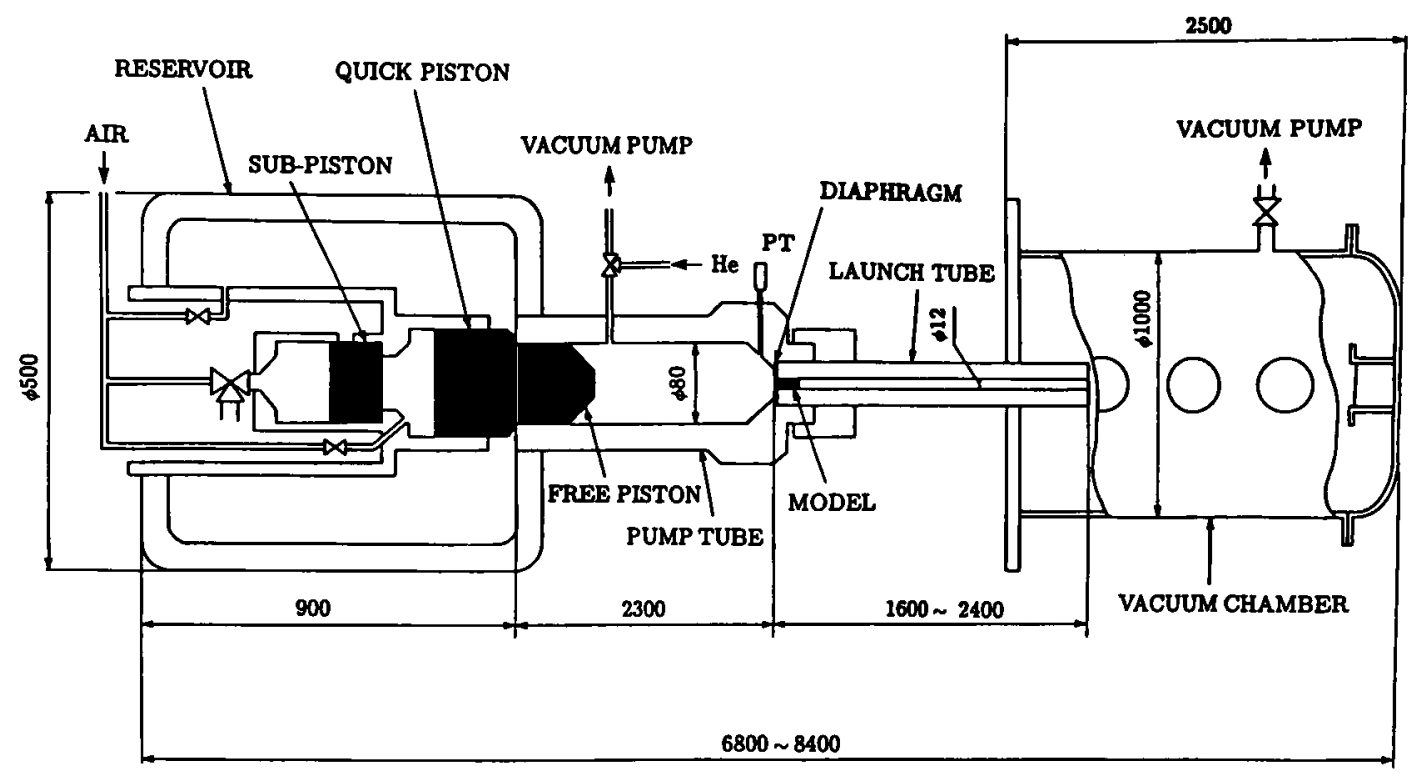

第 1 図 バリスティックレンジの概略図

た ${ }^{3,4)}$ しかしこの現象は複雑な物理化学現象を伴う ため，熱的化学的非平衡現象のモデル化 ${ }^{5)}$ や高温での 化学反応, 電離・解離速度の仮定 ${ }^{6)}$,さらには原子・分 子の放射遷移の簡略化 ${ }^{7}$ などを必要としている。そこ でこれらの計算モデルの妥当性を検討するためには是 非とも実験結果との比較が必要となってきた。

名古屋大学では，鈍頭物体周りの三次元非平衡極超 音速流れ計算 ${ }^{81}$ とその結果を用いた輻射計算 ${ }^{9}$ によっ て輻射熱伝達の解析的な研究を行なってきたが，1991 年にパリスティックレンジ（2段式軽ガス銃）が完成 し，小さなスケールではあるが極超音速，高エンタル ピー流れの実験が可能となった ${ }^{10)}$ そこで本研究では バリスティックレンジより発射された弾の周りから発 せられる輻射光を测定し，その測定結果と計算結果の 比較を試みた。その際に弾と宇宙船の寸法の違いを考 虑して, 衝撃波構造と飛行体モデルの寸法に関するス ケール則を見い出し，実験に用いるべき空気密度など について検討を行なった。

\section{2. 実験装置}

第 1 図に,バリスティックレンジ装置（十合溶材社 製)の概略図を示す。この装置は主に貯気槽，圧縮管， 発射管，観測室により構成されている. 全長が $6.8 \mathrm{~m}$ と，他の同様な装置 ${ }^{11,12)}$ に較べて短いにもかかわら ず，約 $1 \mathrm{~g}$ の弾を秒速 $5 \mathrm{~km}$ で発射することができ る. 1 段部には火薬ではなく高圧空気と高速バルブよ りなる駆動システムが用いられており, 射出速度の再

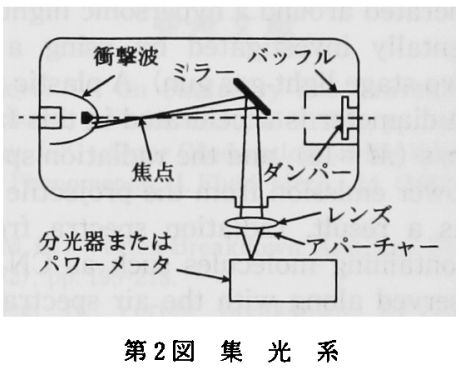

現性向上と装置のセットアップの省力化が図られてい る.およそ 3 時間に 1 回の頻度で実験を行なうことが できる．高速バルブを開くと，貯気槽に蓄えられてい た 5〜8 MPa の高圧空気によりフリーピストンが押し 出され，压縮管内のへリウムが 200〜300 MPa まで压 縮される．この圧力によって，圧縮管と発射管の連結 部にセットされた隔膜が破れ，弾が観測室に向かって 発射される。

発射管内での弾の速度履歴はマイクロ波定在波法を 用いて測定し, 測定室内での飛行速度はレーザーカッ 卜法を用いて測定した。また，超高速度カメラ (NAC，20 Mfps)を使って撮影したシャドウグラフよ り，飛行中の弾の姿勢や破壊状況，衝揧波の形状など を調べた，さらに，弾の周りにできた衝撃波層から発 せられる輻射光のスペクトル分布を分光器（JAS.Co. CT $50 \mathrm{~N}$ ）を用いて観測した。第 2 図に本実験で使用 した集光系を示す 分光写真はインスタントフィルム (Polaroid, ASA 3000) 上に撮影したが, フィルムの 
感度特性からスペクトル分布の撮影可能領域は $330 \sim 650 \mathrm{~nm}$ に限られた。輻射光の強度はダイオード タイプの光パワーメーターを用いて測定した。ダイオ ードタイプのパワーメーターは多少の波長依存性があ るものの，反応時間は $5 \mathrm{~ns}$ と，弾の飛行時間（約 400 $\mu$ s）に対して十分に短く，集光されたパワーの時間履 歴を得ることができる，その履歴は，弾が集光系の焦 点を通過する際に最大値をとる。

\section{3. 実 験 結 果}

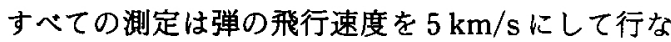
った. 弾の飛行中のシャドウグラフを第 3 図に示す 図に見られるように弾はほとんど原形を保っており， 壇れた様子はない，しかしながら飛行方向に対して幾 分傾いて飛行しているのがわかる。これは高速度力メ ラのシャッターのトリガー信号を得るために発射管出 ロに張った銅線を，弾が横切る際に傾いたものである と考えられる．また弓型衝撃波が弾の前方に生じてい るのがわかる。

輻射光のスペクトル強度分布を第 4 図に示す。この

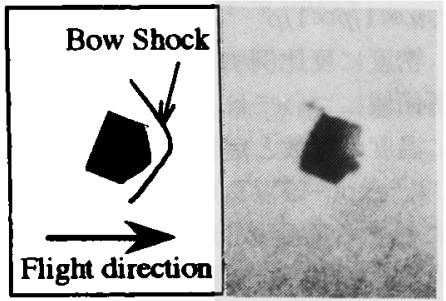

第 3 図 弾の飛行状態のシャドウグラフ(蕗光時間 $100 \mathrm{~ns}$ )
図は分光写真から, $\mathrm{CCD}$ カメラよび画像処理装置 (HAMAMATSU DVS-3000) を用いて強度分布に変 換したものである. 空気分子からのスペクトルの他に $\mathrm{CN} \mathrm{CO}$ といった炭素を含む分子からのスペクトル が同定された，これらの分子は，空気中の二酸化炭素 やすす，弾の材質であるポリエチレンのアプレーショ ン生成物等が、空気中の窒素や酸素と反応した結果生 じたものと考えられる，炭素を含んだ分子は量が少な くても強い輻射を起こすので，これらの輻射も考慮に 入れて熱防御を考える必要があるであろう

次に輻射パワーの時間履歴を第 5 図に示す 弾の発 射時刻は，図中に示されたマイクロ波信号の最大振幅 点から知ることができる，輻射パワーは弾が発射管出 口から出た直後から上昇し，焦点で最大になる，その 後は下降して鏡の横を通過するとほとんど輻射光は観 測されない，弾がダンパーに衝突した後に融解・飛散 して発光し，分光測定に影響を及ほすことのないよう に，ダンパー周りにはバッフルが設けられている。こ の集光系では，焦点において立体角 $8.3 \times 10^{-6} \mathrm{sr}$, 直 径 $23 \mathrm{~mm}$ の円形の FOV (Field of View) が作られる。 焦点において観測される輻射パワーから放射強度を求 めと, 観測室の空気の圧力が $500 \mathrm{~Pa}$ の場合で 31 $\mathrm{W} / \mathrm{m}^{2} \mathrm{sr}$ であった。

\section{4. 極超音速非平衡流れ解析}

衝湦波層内の放射強度分布はその熱的化学的非平衡 性に強く依存する．従って流れ場の計算においては， 有限な反応速度を有する解虧, 電離反応とともに, 分 子の振動励起，電子励起現象を正しく再現しなければ ならない，そこで各化学種, 並進温度、および振動温

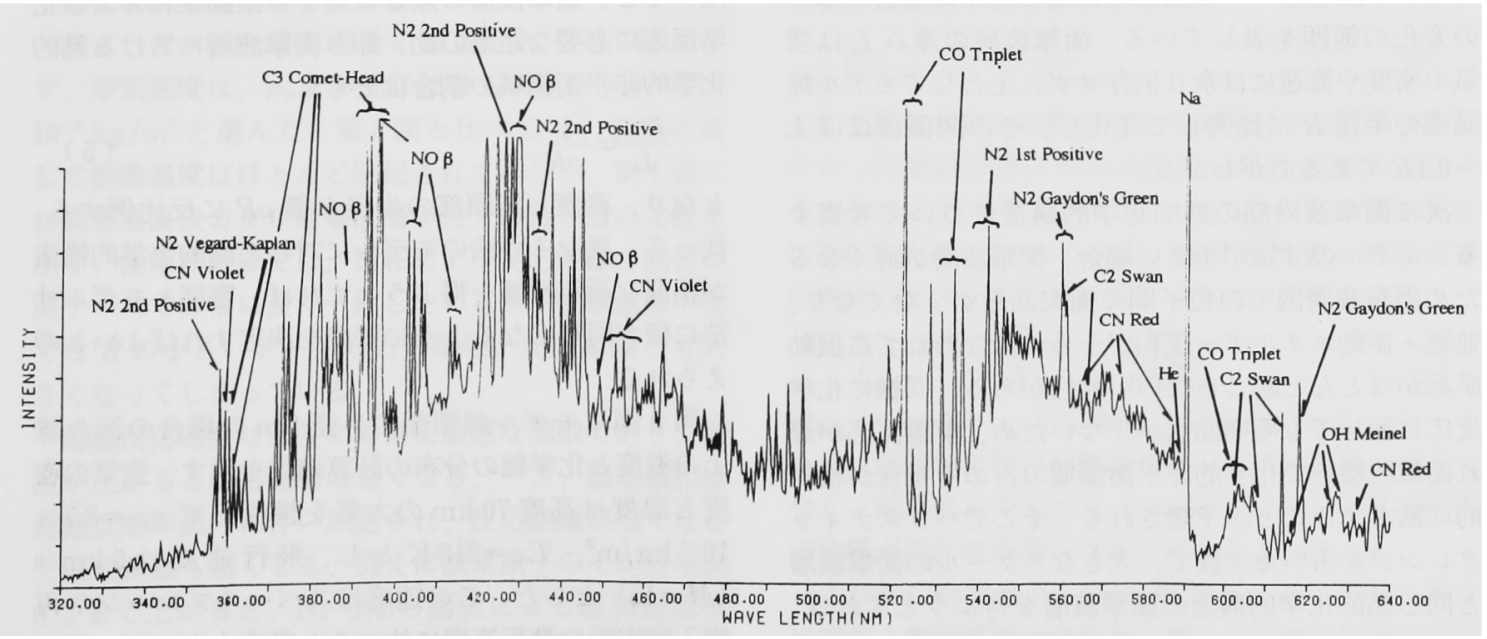

第 4 図 輻射光のスペクトル強度分布 


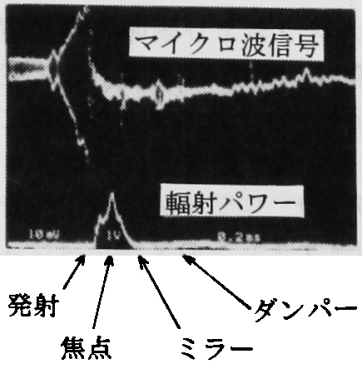

第 5 図輻射パワー履歷

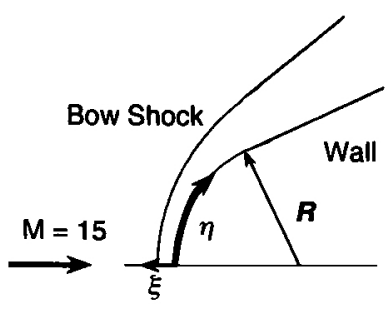

第 6 図鈍頭物体と座標系
度の分布を得るために, 熱的化学的非平衡を考慮した 鈍頭物体周りの軸対称 2 次元数值解析を行なった。計 算に用いた飛行体モデルの形状および座標系を第 6 図 に示す，化学反応に関しては，11の化学種 $\left(\mathrm{N}_{2}, \mathrm{O}_{2}\right.$, $\left.\mathrm{N}, \mathrm{O}, \mathrm{NO}, \mathrm{NO}^{+}, \mathrm{N}^{+}, \mathrm{O}^{+}, \mathrm{N}_{2}^{+}, \mathrm{O}_{2}^{+}, \mathrm{e}^{-}\right)$と電離 反応を含む 17 の素反応を考慮した ${ }^{9)}$. 反応速度係数 はParkの 2 温度反応モデル6)を用い，並進温度と振 動温度の幾何平均の関数として定義した。また並進・ 振動エネルギー緩和に関しては Landau-Teller 型の 緩和を仮定し，その時定数には Millikan and White の半実験式を用いだ) さらに電子温度は振動温度と 等しいと仮定し、飛行体壁面は $1,200 \mathrm{~K}$ の等温壁条 件を仮定した。このような非平衡モデルはかなり一般 的なもので, 計算の妥当性を検討するのに適してい る.

バリスティックレンジょり射出できる弾の寸法は, 実際の飛行船に比へて 2 桁小さく，実験によって飛行 船周りの輻射熱伝達率を見積るには，モデルの寸法の 違いが衝擊波の構造に与える影響を考慮する必要があ る.第 7 図に鈍頭物体の寸法と衝撃波層の厚みの関係 を示す，図中のパーは密度や流速を変えた場合の厚み の変化の範囲を表している。衝撃波層の厚み $L$ は空 気の密度や流速には余り依存せず，主としてモデル鈍 頭部の半径 $R$ に比例して変化し, その関係はほほ $L$ $=0.1 R$ であるのがわかる.

次に衝撃波内部の熱的化学的構造について考察す る、モデルの寸法が小さい場合、衝盤波層が薄くなる ため衝撃波層内での粒子間の衝突回数が少なくなり， 並進・振動エネルギー緩和が十分に行なわれずに振動 励起がほとんど起こらない可能性がある．同様に化学 反応に関しても衝突回数が少ないため，解離反応が遅 れ衝撃波層内で化学的非平衡領域の占める割合が相対 的に拡大することが予想される。そこでバリスティッ クレンジを用いた実験で、大きなスケールの衝揧波層 と同じ熱的化学的構造の衝撃波層を得ようとすれば, 空気の密度を高くして粒子間の衝突頻度を高める必要

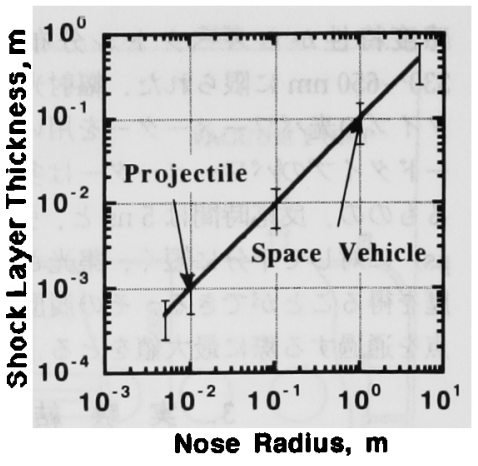

第 7 図衝撃波層の厚み

がある。

実験で用いるべき空気の密度を決定するために，ま ず熱的非平衡領域について考察する．振動緩和の時定 数は次の半実験で表すことができる5)

$$
p \tau_{\mathrm{v}}=\exp \left[a\left(T^{-1 / 3}-b\right)-18.42\right] \text { atm-s (1) }
$$
ここでパラメータ $a, b$ は衝突する 2 つの分子の等価分 子量と特性温度によって定まる定数である。そこで温 度を一定と仮定すれば楥和に必要な距離は

$$
\lambda_{\mathrm{v}}=\tau_{\mathrm{v}} u \propto 1 / p \propto 1 / \rho
$$

と表わせ，密度に反比例することがわかる，一方, 化 学的非平衡領域については, 全ての反応の速度係数は 次のように温度の関数と定義されており

$$
k_{\mathrm{f}}=C T_{\mathrm{a}}^{N} \exp \left(-T_{\mathrm{d}} / T_{\mathrm{a}}\right) \quad \mathrm{cm}^{3} / \mathrm{mol} / \mathrm{s}
$$

解離反応に対する時定数は $\tau_{\mathrm{R}}=1 / k_{\mathrm{f}} n$ と表せるので, 化学的平衡に達するのに必要な距離も振動緩和の場合 と同様に

$$
\lambda_{\mathrm{R}}=\tau_{\mathrm{R}} u \propto 1 / n \propto 1 / \rho
$$

となり，密度に反比例する． $L=0.1 R$ という関係を 用いると，衝撃波層の厚みに対する振動緩和および化 学反応に必要な距離の比, 即ち衝撃波層における熱的 化学的非平衡領域の割合はともに

$$
\frac{\lambda_{\mathrm{V}, \mathrm{R}}}{L} \propto \frac{1}{\rho R}
$$

となり，密度と鈍頭部の半径の積 $\rho R$ に反比例する. 従って, 異なる寸法のモデルに対して熱的化学的棈造 が相似な衝擊波層を得ようとすれば，密度とモデル寸 法に積が同じになるように密度を決定すればよいと考 えられる。

第 8 図にモデル銛頭部の半径 $1 \mathrm{~m}$ の場合の淀み線 上の温度と化学種の分布の計算結果を示す，空気の密 度と温度は高度 $70 \mathrm{~km}$ の大気を模擬して $\rho_{\infty 0}=8.7 \times$ $10^{-5} \mathrm{~kg} / \mathrm{m}^{3}, T_{\infty 0}=218 \mathrm{~K}$ とし, 飛行速度は $5 \mathrm{~km} / \mathrm{s}$ $(M=15)$ とした。この速度はスペースプレーンや再 突入宇宙船の飛行速度に比べると幾分小さいが.我々 


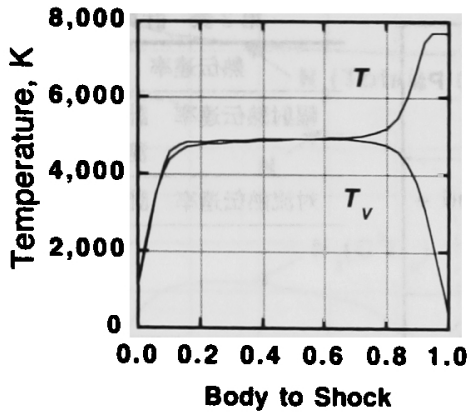

(a) 温度分布

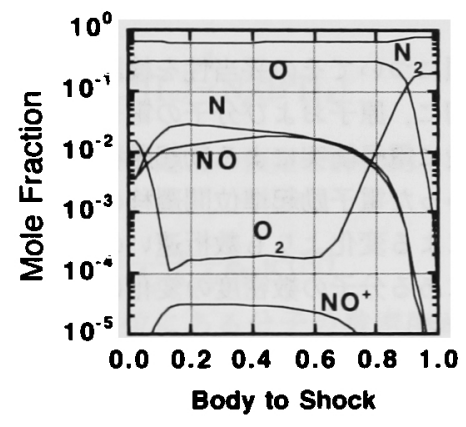

(b) 化学種の分布

第 8 図淀み線上の温度および化学種の分布 $\left(R=1 \mathrm{~m}, \rho_{\infty}\right.$ $=5.7 \times 10^{-5} \mathrm{~kg} / \mathrm{m}^{3}$ )

のバリスティックレンジにより発射できる弾の速度に 等しい 衝典波を通過した直後の並進温度はユゴニオ の関係式より $7,700 \mathrm{~K}$ と求まる。一方振動温度はま だ自由流の温度 $T_{\infty}$ のままであると仮定している．図 からわかるように衝擊波層の厚みの $20 \%$ 程度の距離 で熱化学的平衡に達している.

次に, $R=0.01 \mathrm{~m}$ の場合の温度分布を第 9 図に示 す，空気密度は， $\rho_{\infty} R$ が同じになるように $\rho_{\infty}=8.7 \times$ $10^{-3} \mathrm{~kg} / \mathrm{m}^{3}$ と選んだ、第 8 図と比べると，予想に反 して振動温度はほとんど励起されていない 第 1 表に は衝撃波直後および衝撃波層中央での特性值の比較を 示す，衝撃波直後では，㗔和および反応距離の割合が 両ケースで非常に良く一致しているが, 衝撃波層中央 では $R$ のささいケースの方が䌅和，反応距離とも大 きくなってしまっている。

解離反応速度は温度に非常に敏感な関数であり, 温 度が上がると反応距離は短くなる，一方，振動緩和は 解離反応の進行に伴い加速され，反応距離が短くなる と緩和距離も短くなる。例えは酸素原子のモル分率が 0.3 まで上がると， $\mathrm{N}_{2}-\mathrm{O}$ 間の衝笑による縓和速度俰 数は $\mathrm{N}_{2}$ 同士の衙突によるものよりも 1 桁大きくな

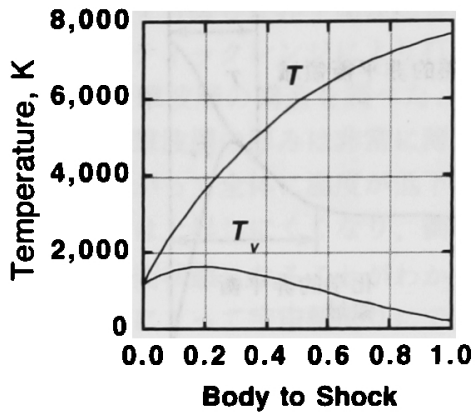

第 9 図腚み線上の温度分布 $\left(R=0.01 \mathrm{~m}, \rho_{\infty}=5.7 \times 10^{-s}\right.$ $\mathrm{kg} / \mathrm{m}^{3}$ )

第 1 表 衝慗波直後および中央での特性值の比較

\begin{tabular}{clll}
\hline 計算条件 & $R, \mathrm{~m}$ & 1.00 & 0.01 \\
& $\rho, \mathrm{kg} / \mathrm{m}^{3}$ & $8.7 \times 10^{-5}$ & $8.7 \times 10^{-3}$ \\
\hline 衝擊波層厚さ & $L / R$ & $7.50 \times 10^{-2}$ & $9.00 \times 10^{-2}$ \\
\hline 衝撃波直後 & $T_{\mathrm{a}}, \mathrm{K}$ & 1.295 & 1.295 \\
& $\lambda_{\mathrm{V}} / R$ & $4.95 \times 10^{-2}$ & $4.87 \times 10^{-2}$ \\
& $\lambda_{\mathrm{R}} / R$ & $5.42 \times 10^{13}$ & $5.36 \times 10^{19}$ \\
\hline 衝擊波層中央 & $T_{\mathrm{a}}, \mathrm{K}$ & 4.915 & 2.661 \\
& {$[\mathrm{O}] /[\mathrm{M}]$} & 0.30 & 0.05 \\
& $\lambda_{\mathrm{v}} / R$ & $1.07 \times 10^{-2}$ & $1.00 \times 10^{-1}$ \\
& $\lambda_{\mathrm{R}} / R$ & $2.36 \times 10^{-1}$ & $4.64 \times 10^{3}$ \\
\hline
\end{tabular}

る. 従って緩和, 反応距離の相異は, 結局は温度分布 の違いに起因している。

この衝摮波層内の温度分布に大きな影響を及ほすを 考えられるのが温度境界層である，飛行体の固体壁が 冷却や放射によって一定温度に保たれていると，壁付 近には第 8 図に見られたように温度境界層が生じる。 その模式図を第 10 図に示す 温度境界層の厚みは次 のように見積ることができる。

$$
\delta_{\mathrm{T}} \sim \sqrt{\frac{x}{\rho C_{\mathrm{p}}}} \propto \frac{1}{\sqrt{\rho_{\infty}}}
$$

ここで熱伝導率と比熱はともに温度だけの関数である から, 温度境界層の厚みは密度の平方根に反比例す る. その比例定数を第 8 図から求めると, 壁面温度 $1,200 \mathrm{~K}$ でほほ 0.01 となり，温度境界層と衝撃波層 の厚みの比は次のように表わすことができる。

$$
\frac{\delta_{\mathrm{T}}}{L}=\frac{0.01 / \sqrt{\rho_{\infty} / \rho_{\infty 0}}}{0.1 R}=\frac{0.1}{\sqrt{R / R_{0}}}
$$

従って， $\rho_{\infty} R$ を一定に保ちながらモデルを小さくす ると, 温度境界層の影響はモデル寸法は次第に大きく なり, 鈍頭部の半径が $0.01 \mathrm{~m}$ 以下になると衝撃波層 の全域が温度境界層に支配されることになる．

これらの結果から，1 cm 程度の小さなモデル周り にできる衝撃波層は全領域に渡って熱的化学的に非平 


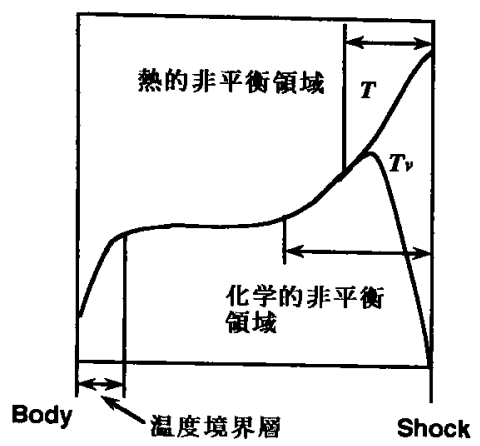

第 10 図衝擊波層内の温度分布と温度境 界層

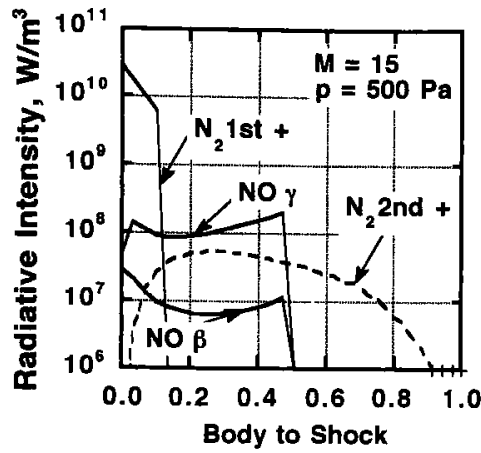

第 11 図 淀み線上の各遷移の放射強度分布
第 2 表 計算と実験の比較

\begin{tabular}{|c|c|c|}
\hline \multicolumn{2}{|c|}{ 熱伝垟率 } & $\mathrm{kW} / \mathrm{m}^{2}$ \\
\hline 輻射熱伝達率 & 計算值 & $6.4 \times 10^{1}$ \\
\hline & 測定值 & $2.0 \times 10^{-1}$ \\
\hline 対流熱伝澾率 & 計算値 & $2.3 \times 10^{3}$ \\
\hline
\end{tabular}

衡で，スペースプレーンのような大型の飛行体の周り にできる衝撃波層の構造とはかなり異なるものである ことがわかった：そのため衝撃波層からの輻射熱伝達 率を求めるには同程度のスケールのモデルで実験を行 なうか，輻射現象をモデル化した数值計算を行なう必 要がある。

\section{5. 輻 射 計 算}

まず計算結果と実験結果を比較するために計算条件 を実験条件に合わせて， $T_{\infty}=300 \mathrm{~K}, p_{\infty}=500 \mathrm{~Pa}$ と し, 流れ計算によって各化学種の数密度, および並 進・振動温度の分布を求めた．計算結果は示さないが 第 9 図の結果と同様に，振動エネルギー緩和は遅れて 衝揧波層内部は完全に熱的非平衡状態になり，電離反 応は起こらずに電子はほとんど生じなかった，次に， その結果を用いて放射強度抢よび吸収係数を求め飛行 体前方への輻射熱伝達率を見積った，計算にはP Park の開発した空気の輻射計算コード》（NEQAIR）を用 い，主要な輻射遷移として中性原子の Bound-Bound, Bound-Free 遷移, イオンの Bound-Bound, BoundFree, Free-Free 遷移, 分子の電子励起-振動-回転準 位間遷移 $\left(\mathrm{N}_{2}\right.$ first positive, second positive, $\mathrm{O}_{2}$ Schuman Runge, $\mathrm{NO} \beta, \gamma, \mathrm{N}_{2}^{+}$first negative の各バン ドシステム) を考慮した。

第 11 図に淀み線上の各遷移の放射強度分布を示す 分子からの放射，特に $\mathrm{NO}$ と $\mathrm{N}_{2}$ からの放射が支配的 であり，原子からの放射はほとんど見られない。これ は電子密度が非常に小さいためであり, スペクトル分 布の測定結果と定性的に良く一致する。次に輻射熱伝 達率を実験結果と比較すると，第 2 表に示すように計 算値は測定值よりも2桁大きな値になった。これは， 壁付近の低温領域からの $\mathrm{N}_{2}$ first positive 遷移の強い 放射が、実際よりも大きく見積られてしまっているた めではないかと考えられる。そこで計算に用いられた
仮定と手順についてその妥当性を検討する。

まず最初に，原子および分子の電子励起状態を計算 する。一般に電子衝突による励起遷移や輻射を伴う失 活遷移といった電子励起準位間遷移の速度は，化学反 応や拡散による変化よりも数桁速いので，以下のよう に各準位にある分子の数密度の変化について準定常状 態を仮定する。

$$
\sum_{j}\left(K_{j i} n_{e}+A_{j i}\right) n_{j}-\sum_{i}\left(K_{i j} n_{e}+A_{j i}\right) n_{i}=\frac{\partial n_{i}}{\partial t}=0
$$

添字は電子励起準位を表す 分子の場合にはこれらの 遷移に加えて, 重粒子の衝突による解離と再結合によ る遷移を考慮しなければならない（原子の電離反応に ついても同様な扱いが必要). 各電子励起準位から解 離状態への遷移反応速度係数 $K_{i c}$ は，流れ場の計算の 場合と同様に半実験式で表せるものとする.

$$
K_{i c}=C T^{N} \exp \left(-D_{i} / k T\right)
$$

ここで $C$ と $N$ は分子や原子の種類や数密度比などか ら定まる定数， $D_{i}$ は $i$ 番目の電子励起準位加らの解 離エネルギーである.一方その逆反応の遷移反応速度 係数 $K_{c i}$ は，解離反応式 $A B \leftrightarrow A+B$ に抢いて詳細釣 り合いの原理

$$
\frac{K_{i c}}{K_{c i}}=\frac{n_{A} n_{B}}{\left(n_{A B}\right)_{i E}}=k_{e q}\left(T, T_{\mathrm{V}}, D_{i}\right)
$$

が成り立つとして, 各分子原子の分配関数より平衡定 数 $k_{e q}$ を求め, これを(8) 式に代入して連立方程式を 解き，電子励起状態を決定する。

$\mathrm{N}_{2}$ の second positive 遷移を例にとって具体的に計 算手順を示す この遷移の上位電子励起準位 $C^{3} \Pi_{\mathrm{u}}$ は 解離エネルギーよりも高い準位なので，電子衝突によ る励起はほとんで考虑する必要が無く，重粒子の衝突 による分子の前期解離 (Pre-dissociation) $k_{\mathrm{p}}$ とその逆 反応 (Inverse Pre-dissociation) $k_{\mathrm{lp}}$, および輻射を伴 う失活遷移によって平衡状態が成り立っている。 


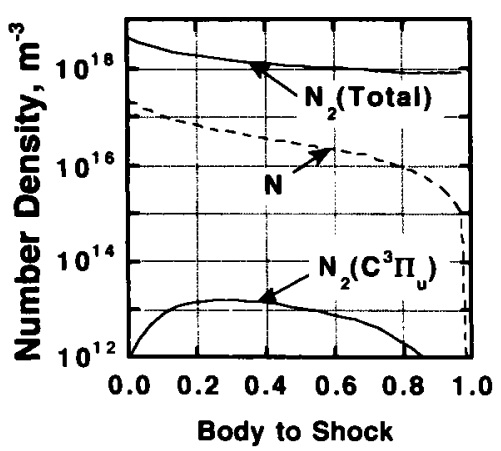

第 12 図淀み線上の $\mathrm{N}_{2} \mathrm{C}^{3} \Pi_{\mathrm{U}}$ 準位の数密度分布

$$
\mathrm{N}+\mathrm{N} \underset{k_{\mathrm{p}}}{\stackrel{k_{\mathrm{p}}}{\rightleftarrows}} \mathrm{N}_{2}\left(\mathrm{C}^{3} \Pi_{\mathrm{u}}\right) \stackrel{A}{A} \mathrm{~N}_{2}\left(\mathrm{~B}^{3} \Pi_{\mathrm{g}}\right)
$$

この反応に関して準定常の仮定と詳細釣り合いの原理 を適用すると

$$
n\left(\mathrm{~N}_{2} \mathrm{C}^{3} \Pi_{\mathrm{u}}\right)=\frac{k_{\mathrm{p}}}{k_{\mathrm{p}}+A} k_{e q} n^{2}(\mathrm{~N})
$$

となり， $\mathrm{C}^{3} \Pi_{\mathbf{u}}$ 準位にある分子の数密度が求められ る．放射強度はこの準位の数密度によって決まる。第 12 図に淀み線上の $\mathrm{C}^{3} \Pi_{\mathrm{u}}$ 準位の数密度分布を示す $n\left(\mathrm{~N}_{2} \mathrm{C}^{3} \Pi_{\mathrm{u}}\right)$ は解離反応が進むにつれて堌加し, 壁付 近で温度が下がり $k_{\mathrm{p}}$ が小さくなると減少する

$\mathrm{N}_{2}$ の first positive 遷移の場合は $\mathrm{B}^{3} \Pi_{\mathrm{g}}$ 準位からの 要移なので，その準位の占有率が高いと強い輻射が見 られる。壁付近でこの遷移の放射強度が異常に大きく なった原因は, 低温度, 高解離率という強い非平衡状 態において再結合反応速度が高めに見積られ， $\mathrm{B}^{3} \Pi_{\mathrm{g}}$ 準位の占有率が過大に評価されたためではいかと考 えられる。

壁付近の物理現象のモデル化においては，さらに固 体壁のアフレーションを考慮して温度, 化学種の分布 を决めないと計算で得られる輻射量は実験結果と一致 しないであろう 今後は壁面での物理現象の詳しい解 析が必要である。

$$
\text { 6.おわりに }
$$

バリスティックレンジを用いて衝撃波層より発せら れる輻射光を定量的に測定することができ, 解析結果 との比較が可能になった。また測定されたスペクトル 分布からは炭素を含む分子からの輻射が多数同定さ れ，今後はアブレーション生成物からの輻射を考慮す る必要があることが示された。バリスティックレンジ によって作り出される衝擊波層は光学的に薄く, 壁付 近からの輻射光が観測しやすいため, 壁面付近の物理 現象の研究に役立つであろう
次にモデル寸法を考慮した非平衡極超音速流れ解析 によって、バリスティックレンジにより打ち出される 弾周りにできる衝撃波層の構造を調へた。その結果， 弾周りにできる衝撃波層の厚みは非常に薄く，相対的 に温度境界層が広がって全体に温度が低下し，化学反 応は遅れ振動温度は上昇しにくくなり、衝撃波層全体 が熱的化学的非平衡状態になることがわかった。シミ ュレーション実験によって宇宙船周りにできる衝撃波 層と熱化学的に相似な衝撃波層を得ようとするなら ば，（7）式に示したように少なくとも寸法の1桁大き な $10 \mathrm{~cm}$ のオーダーの飛行体モデルが必要であり， その場合にはラム加速器などの装置が有望であろう.

最後に輻射熱伝達率の測定結果と計算結果を比較 し, 計算モデルの妥当性を検証した。その結果、計算 值は測定值よりも2 桁大きく，壁付近の低温度領域で の放射強度の計算に問題があることがわかった。正確 な熱伝達率の見積にはさらに詳しい研究が必要とさ れ，今後も実験結果と計算結果を比較しながら計算モ デルの検証を行なっていく予定である.

\section{参考文献}

1) Walberg, G. D. . A Survey of Aeroassisted Orbit Transfer, J. Spacecraft and Rockets, 22 (1985), pp. 3-18.

2) Howe, J. T. . Introductory Aerothermodynamics of Advanced Space Transportation Systems, J. Spacecraft and Rockets, 22 (1985), pp. 19-26.

3) Park, C.: Radiation Enhancement by Nonequilibrium in Earth's Atmosphere, J. Spacecraft and Rockets, 22 (1985), pp. 27-36.

4) Gokçen, T.: Computation of Nonequilibrium Radiating Shock Layers, AIAA 93-0144, 1993.

5) Millikan, R.C. and White, D. K.: Systematics of Vibrational Relaxation, J. Chem. Phys., 139 (1963). pp. 3209-3213.

6) Park, C. . Assessment of Two-Temperature Kinetic Model for Ionizing Air, J. Thermophysics and Heat Transfer, 3 (1989), pp. 233-244.

7) Park, C.: Calculation of Nonequilibrium Radiation in AOTV Flight Regimes, AIAA 84-0306, 1984.

8) Reddy, K. V., Fujiwara, T. and Murayama, T.: Ther. mally and Chemically Nonequilibrium Flow Analyzed by Park's Two-Temperature Model, AIAA Paper 900142, 1990.

9）佐宗章弘，張 新宇，村山俊之，藤原俊隆：再突入時に形 成される極超音速非平衡衝波層加らの輻射熱伝達、日本 航空宇宙学会誌, 39 (1991)，pp. 531-538.

10) Chang, X., Hemmi, M., Komurasaki, K. and Fujiwara, $T$.: Radiation Measurements by Using a Ballistic Range, AIAA Paper 93-0635, 1993.

11) Dietz, K. L., Beale, K.S. and McGregor, W.K. . Ultraviolet/Visible Spectral Radiation from the Nose Cap of a Projectile Launched in a Ballistic Range, AIAA Paper 90-1552, 1990.

12) Sharma, S. P. and Gillespie, W.: Nonequilibrium and Equilibrium Shock Front Radiation Measurement, J. Thermophysics, 5 (1991), pp. 257-265. 